\title{
Glutamate Receptor Gene Expression in Spinal Cord of Arthritic Rats
}

\author{
Domenico E. Pellegrini-Giampietro,, ${ }^{1, a}$ Shaoguang Fan, ${ }^{1}$ Brian Ault, ${ }^{2}$ Bruce E. Miller, ${ }^{2}$ and R. Suzanne Zukin' \\ 'Department of Neuroscience, Albert Einstein College of Medicine, Bronx, New York 10461 and ${ }^{2}$ Sterling Winthrop \\ Pharmaceuticals Research Division, Rensselaer, New York 12144
}

Injury to peripheral tissue leads to hyperalgesia that appears to be partly mediated by functional changes at the level of the spinal cord. Glutamate receptors are thought to play a role in acute and short-term (minutes to hours) spinal cord nociceptive responses and may be involved in prolonged or chronic pain (hours to days). We used in situ hybridization to examine AMPA/kainate (GluR1, GluR2, and GluR3) and NMDA (NR1) receptor gene expression in spinal cord following induction of prolonged inflammation by a unilateral intraarticular injection of lipopolysaccharide (LPS; $10 \mu \mathrm{g}$ ) into the hindpaw. In control rats, GluR1 expression was prominent throughout the layers of the gray matter of the spinal cord. Microscopic examination revealed labeling of neuronal cell somata in all major nuclei. GluR2 was abundant in substantia gelatinosa and motor nuclei; emulsion-dipped sections exhibited intense labeling over densely packed neurons in the superficial laminae of dorsal horn and individual motoneurons of ventral horn. GluR3 and NR1 were expressed at low levels throughout spinal cord gray matter. One day after LPS injection, when joint swelling was maximal, GluR 1 expression was bilaterally decreased by $25 \%$ in the substantia gelatinosa at the level of the lumbar cord. In contrast, no significant change was apparent in GluR2, GluR3, or NR1 expression in any nucleus of the cord. At $72 \mathrm{hr}$ after injection, when joint diameter approached control values, all four transcripts were expressed at near control levels. These findings provide evidence for a specific decrease in GluR1 expression in the cord in response to joint inflammation.

IKey words: AMPA, kainate, NMDA, inflammation, in situ hybridization, excitatory amino acid receptors, spinal cord plasticity]

Nociceptive information from the periphery is transmitted by finc myclinated and unmyclinated fibcrs that lic principally in the lateral portion of the dorsal roots of the spinal cord. These fibers terminate in superficial laminae $(1-3)$ of the dorsal horn (see Willis, 1985). Excitatory amino acids (EAAs) are thought

Received April 5, 1993; revised Aug. 17, 1993; accepted Aug. 26, 1993.

Wc thank Drs. R. Axcl, S. Hcincmann, and P. Sceburg for providing the GluR1 (GluR-A), GluR2 (GluR-B), and GluR3 (GluR-C) cDNAs, Dr. S. Nakanishi for providing the NRI cDNA, Mr. D. J. Koonz for preparing the animals, and Mr. P. Yellin for excellent technical assistance. This work was supported by National Institutes of Health Grant NS20752 to R.S.Z. and Sterling Winthrop Pharmaceuticals Research Division.

Correspondence should be addressed to Dr. R. Suzanne Zukin, Department of Neuroscience, Albert Einstein College of Medicine, 1300 Morris Park Avenue, Bronx, NY 10461.

${ }^{2}$ Present address: Dipartimento di Farmacologia Preclinica e Clinica, Università di Firenze, Viale Morgagni 65, 50134 Firenze, Italy.

Copyright $(1994$ Society for Neuroscience $0270-6474 / 94 / 141576-08 \$ 05.00 / 0$ to be neurotransmitters or cotransmitters of nociceptive afferents. Glutamate is colocalized with substance $\mathrm{P}$ in small dorsal root ganglion neurons (Battaglia and Rustioni, 1988) as well as small-diameter primary afferent terminals in dorsal laminae of spinal cord (De Biasi and Rustioni, 1988; Miller et al., 1988). Autoradiography studies have noted a high density of NMDA and $\alpha$-amino-3-hydroxy-5-methyl-4-isoxazole propionic acid (AMPA)/kainate receptors in the rat and human dorsal horn (Monaghan and Cotman, 1982, 1985; Jansen et al., 1990; Henley et al., 1993). Behaviorally, spinal administration of EAAs results in dose-dependent agitation and vocalization ( $\Lambda$ anonsen and Wilcox, 1989; Malmberg and Yaksh, 1992), whereas glutamate receptor antagonists produce analgesia (Cahusac et al., 1984; Dickenson and Aydar, 1991; Murray et al., 1991; Nasstrom et al., 1992).

Injury to peripheral tissue leads to increased sensitivity to noxious stimuli (hyperalgesia) that appears to involve long-term functional changes in the spinal cord, as evidenced by increased postsynaptic neuron excitability and responsiveness, changes in gene expression, and morphological or functional modifications of the afferent terminal (for reviews, see Woolf et al., 1988; Wilcox, 1991; Dubner and Ruda, 1992). Glutamate receptors of the AMPA/kainate type preferentially mediate spinal monosynaptic reflexes (Ganong et al., 1983; Jahr and Jessel, 1985; Morris, 1989; Long et al., 1990) and acute nociceptive responses (Dickenson and Sullivan, 1990; Ault and Hildebrand, 1991). Conversely, NMDA receptors are implicated in polysynaptic spinal pathways (Watkins and Evans, 1981; Watkins, 1984) and participate in short-term (minutes to hours) neuronal plasticity, as for example, the phenomenon of "wind up" (frequency-dependent potentiation of dorsal horn nociceptive neurons to repetitive afferent stimulation) (Davies and Lodge, 1987; Dickenson and Sullivan, 1987) or the hyperexcitability induced in spinal cord neurons by chemical stimulation of nociceptors $(\mathrm{Ha}-$ ley et al., 1990; Woolf and Thompson, 1991). The role of glutamate neurotransmission in longer-term (hours to days) changes related to chronic pain states is less clear (see Wilcox, 1991). These mechanisms may include increased release of glutamate (Skilling et al., 1988; Sorkin et al., 1992) or neuropeptides (Garry and Hargreaves, 1992) in dorsal horn following noxious stimulation, potentiation of spinothalamic neuron responses to EAAs (Dougherty et al., 1992), sprouting of afferent terminals into lamina 2 (Cameron et al., 1991; Woolf et al., 1992), and changes in spinal neuron gene or protein expression (see Dubner and Ruda, 1992). These findings implicate glutamate receptors in the mechanisms of enhanced neuronal responsiveness and hyperalgesia associated with arthritis-like inflammation.

AMPA/kainate-sensitive glutamate receptors are encoded by a family of four genes designated GluRl through GluR4 (for 
reviews, see Gasic and Hollmann, 1992; Sommer and Seeburg, 1992). Differential splicing in the second cytoplasmic loop of the proteins yields receptor variants designated "flip" and "flop" (Sommer et al., 1990). Recombinant receptor channels expressed in Xenopus oocytes or in mammalian cells can be activated by AMPA, kainate, quisqualate, and glutamate. The subunit composition of AMPA/kainate receptors determines their functional properties. GluR 1 homomeric channels exhibit higher affinity for agonists (Gasic and Hollmann, 1992; Stein et al., 1992); in heteromeric channels the GluR2 subunit governs the $\mathrm{Ca}^{2+}$-permeability and current-voltage relationship properties (Hollmann et al., 1991; Verdoorn et al., 1991; Burnashev et al., 1992). Data from in situ hybridization (Keinänen et al., 1990; Pellegrini-Giampietro et al., 1991) and electrophysiological (Jonas and Sakmann, 1992) experiments indicate that native AMPA/kainate receptors in most adult neurons are heterooligomers containing Glur 1 and the GluR2 subunit.

To date, two gene families encoding NMDA receptor subunits have been identified in rat brain. One family is composed of the NR 1 gene (Moriyoshi et al., 1991). NR1 undergoes alternate splicing at the $\mathrm{N}$ - and $\mathrm{C}$-terminal ends of the NR1 protein to give rise to eight possible receptor variants (Anantharam et al., 1992; Durand et al., 1992; Sugihara et al., 1992; Hollmann et al., 1993). In functional expression systems, each of these variants forms homomeric channels that share many of the electrophysiological and pharmacological properties of native NMDA receptors. The second family is composed of the NR2AC subunits (Monyer et al., 1992), also known as $\epsilon 1-\epsilon 3$ (Kutsuwada et al., 1992; Meguro et al., 1992); subunits of this family do not form functional homomeric channels, but show greatly enhanced NMDA receptor activity when coassembled with NR1 subunits.

Lipopolysaccharide (LPS) injection into the ankle joint of rats provides a model of relatively acute arthritis in which long-term spinal cord responses can be studied (Goldenberg et al., 1984; Esser et al., 1986; Stimpson et al., 1987). In the present study we used in situ hybridization to examine cell-specific expression of GluR1, GluR2, GluR3, and NR1 in the spinal cord of LPSinjected rats. We show that joint inflammation leads to a selective reduction of GluR 1 expression in neurons of the substantia gelatinosa.

\section{Materials and Methods}

All research involving animals reported in this publication was performed in accord with the Sterling Winthrop Pharmaceuticals Research Division's (SWPRD) Policy on Animal Use, and all national and federal legislation. All SWPRD animal facilities and programs are accredited by the American Association for Accreditation of Laboratory Animal Care (AAALAC).

Induction of inflammation in rats. LPS isolated from Salmonella minnesota (Calbiochem) was injected intra-articularly into the right ankle joint of isoflurane-anesthetized female Lewis rats $(250-300 \mathrm{gm})$ at a dose of $10 \mu \mathrm{g}$ in $10 \mu \mathrm{l}$ of saline using a 26 gauge needle. Control animals received an equal volume of saline. Ankle diameter measurements were determined for both LPS-injected and control joints using vernier calipers, and the size difference (right minus left, in $\mathrm{mm}$ ) noted for separate groups of rats at 6,24 , and $72 \mathrm{hr}$ postinjection. Following joint measurements rats were anesthetized with carbon dioxide, decapitated, and the spinal cord removed from the spinal column by rapid caudal injection of $10 \mathrm{ml}$ of diethylpyrocarbonate-treated autoclaved saline. Spinal cords were immediately frozen on dry ice and stored at $-70^{\circ} \mathrm{C}$. Induction of inflammation in rats, ankle diameter measurements, and harvest and freezing of spinal cords were all performed at Sterling Winthrop. Cords were collected, transferred to dry ice, and shipped to the Albert Einstein College of Medicine.
In situ hybridization. Immediately upon arrival, fresh-frozen cross sections $(20 \mu \mathrm{m})$ of spinal cord from experimental and control animals were cut in a cryostat, thaw mounted onto gelatin/poly(L-lysine)-coated slides, and postfixed with $4 \%$ paraformaldehyde. In situ hybridization was performed under conditions of high stringency, as described (Pellegrini-Giampietro et al., 1991), to localize and measure glutamate receptor mRNAs in spinal cord by one of us (S.F.) who was blind to the experimental treatment. Briefly, ${ }^{35} \mathrm{~S}-\mathrm{UTP}$-labeled antisense RNA probes were directed against GluR1, GluR2, GluR3, and NR1 mRNAs as described (Pellegrini-Giampietro et al., 1991). GluR1, GluR2, and GluR3 are "pan" probes (Sommer et al., 1990) in that they label both "flip" and "flop" splicc variants. Aftcr acctylation with acctic anhydride $(0.25 \%)$, sections were incubated $\left(50^{\circ} \mathrm{C}, 2 \mathrm{hr}\right)$ with $100 \mu \mathrm{l}$ of prehybridization solution $[50 \%(\mathrm{v} / \mathrm{v})$ formamide, $2.5 \times$ Denhardt's solution, $0.6 \mathrm{M} \mathrm{NaCl}$ $10 \mathrm{~mm}$ Tris- $\mathrm{HCl}, \mathrm{pH} 7.4,1 \mathrm{~mm}$ EDTA, $0.05 \%$ sodium dodecyl sulfate, herring sperm DNA $(150 \mu \mathrm{g} / \mathrm{ml})$, total yeast RNA $(50 \mu \mathrm{g} / \mathrm{ml})]$. Slides were then incubated $\left(50^{\circ} \mathrm{C}\right.$, overnight) with $50 \mu \mathrm{l}$ of prehybridization solution containing $10 \mathrm{~mm}$ dithiothreitol, $10 \%(\mathrm{w} / \mathrm{v})$ dextran sulfate, and ${ }^{35} \mathrm{~S}$-UTP-labeled RNA probe $\left(10^{6} \mathrm{cpm} / \mathrm{section}, 1 \mathrm{ng} / \mu \mathrm{l}\right)$. The following day sections were incubated in RNase A $(20 \mu \mathrm{g} / \mathrm{ml})$ and washed in $0.2 \times$ saline-sodium citrate for $2 \mathrm{hr}$ at $50^{\circ} \mathrm{C}$. Following hybridization, sections were apposed ( $24 \mathrm{hr})$ to Kodak XAR-5 film or, for higherresolution studies, dipped in Kodak NTB-2 nuclear emulsion, developed after $8 \mathrm{~d}$, and counterstained with hematoxylin and eosin. Sense RNA probes did not label, and pretreatment with RNase A (100 $\mu \mathrm{g} /$ $\mathrm{ml}$ ) prior to hybridization prevented labcling. Spccificity of GluR1, GluR2, and GluR3 probes was assessed by competition experiments using a 10-fold excess of unlabeled cRNAs (Pellegrini-Giampietro et al., 1991); hybridization to any given probe was blocked nearly completely by preincubation of sections with an excess of the corresponding unlabeled cRNA but was not blocked by preincubation with the other cRNAs. It was therefore assumed that experimental conditions were stringent enough to rule out GluR4 cross-hybridization as well; moreover, GluR4 is expressed at background levels in spinal cord (Henley et al., 1993). Other glutamate receptor-related subunits (GluR5, GluR6, GluR7, KA1, and KA2) exhibit less than $40 \%$ homology with GluR1GluR4 (Gasic and Hollmann, 1992; Sommer and Seeburg, 1992) and thus should not have been labeled. The NR1 probe is unlikely to crossreact with NR2A-C, which share less than $20 \%$ sequence identity with NR1 (Kutsuwada ct al., 1992; Monyer ct al., 1992).

Quantitative analysis. The rationale of the quantitative analysis (see also Pellegrini-Giampietro et al., 1991, 1992) was based on the constant relationship between densities in film autoradiograms and number of grains overlying individual neurons in emulsion-dipped sections. Optical densities and number of grains per cell for a given region of interest varied little in different sections from the same animal. The concentration of RNA probe used $\left(10^{6} \mathrm{cpm} / 80 \mu \mathrm{l}\right.$ per section) produced saturating levels of hybridization and afforded the maximal signal-to-noise ratio for the probes used. Preexposure of films and analysis of ${ }^{35} \mathrm{~S}-\mathrm{UTP}-$ labeled brain paste standards indicated that exposure times were in the linear response range of the film. Corresponding spinal cord sections from rats killed at different times after LPS or saline injection were cut in the same session, incubated with the same solutions of GluR1, GluR2, GluR3, or NR1 probes, and apposed to the same sheet of film. Autoradiograms were analyzed with a Molecular Dynamics model $300 \mathrm{~A}$ computing densitometer (Sunnyvale, CA). Optical densities of pixels overlying regions of interest from a minimum of four different sections per rat were corrected for background (optical density of the film), averaged, and normalized to the values of the corresponding regions in control sections for a given film. Little variability was observed in optical density values from a given subregion of control sections present in all films (see Table 2; all SEM values $<10 \%$ of the mean). Values are reported as normalized means \pm SEM (Table 2) and as percentage of normalized optical densities \pm SEM (Figs. 3-4). Since right and left optical density readings were not detectably different, they were averaged and calculated as a single value for each spinal cord region (see Figs. 3, 4). Mean experimental values were compared with mean control values by use of the Mann-Whitney two-tailed $U$ test.

\section{Results}

Autoradiograms of cross sections of lumbar spinal cord from control rats hybridized to antisense RNA probes for GluR1, GluR2, GluR3, and NR1 showed specific labeling of the gray matter, with distinctive topographic distributions (Fig. 1). Pat- 


\section{CONTROL}

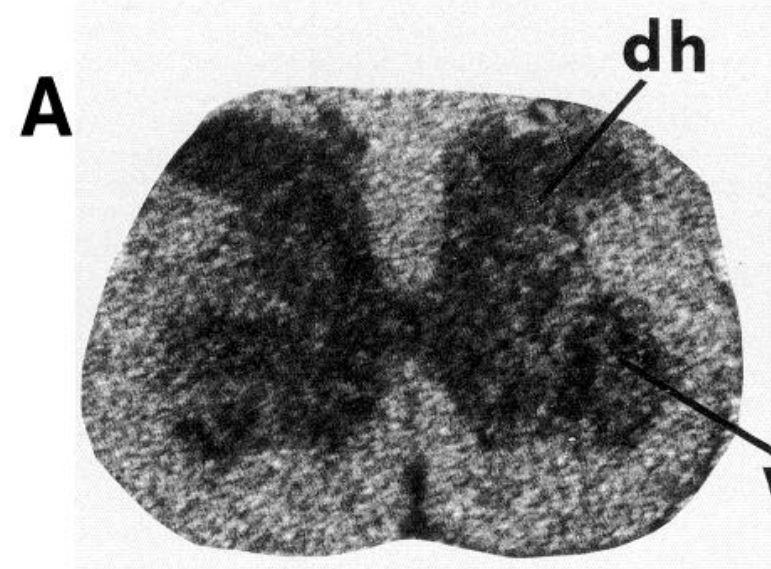

C

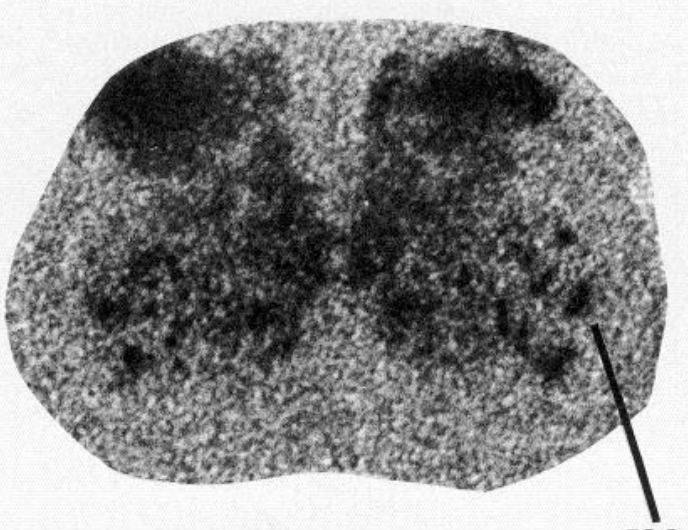

E

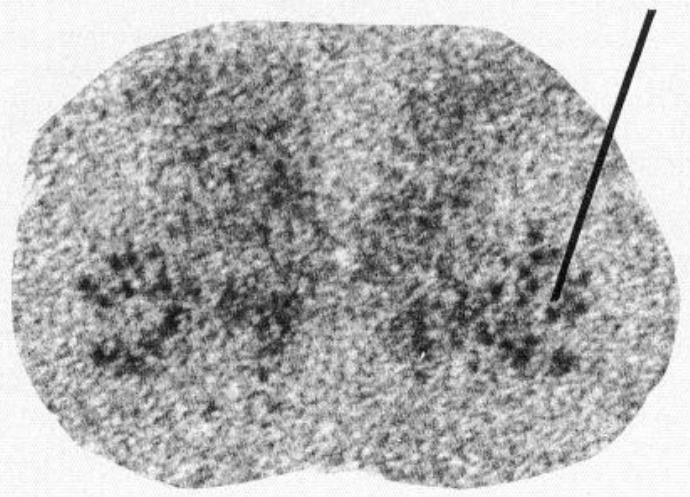

G

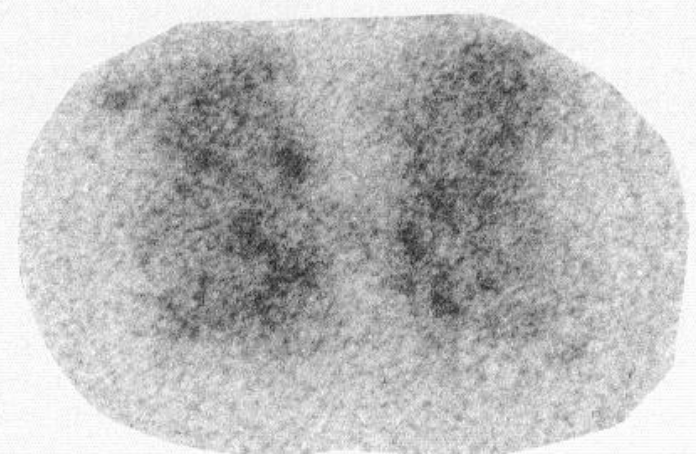

ARTHRITIC

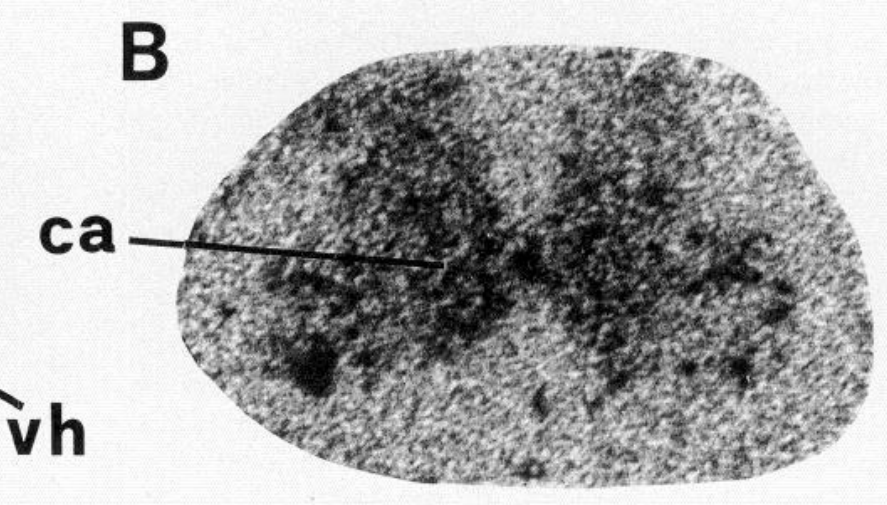

D
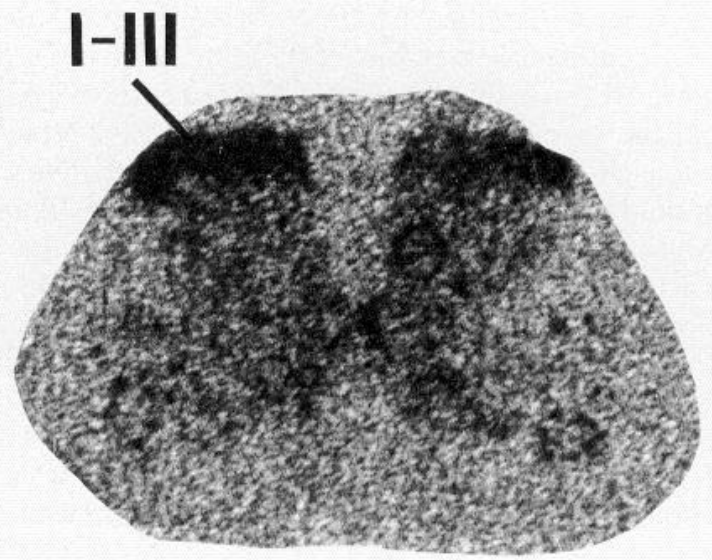

F

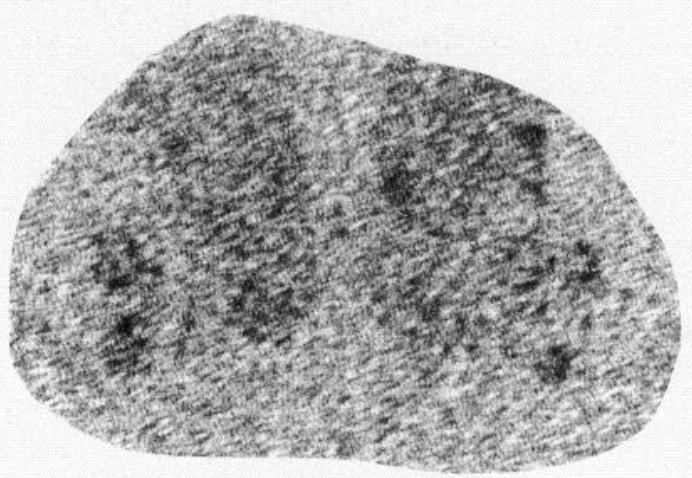

H

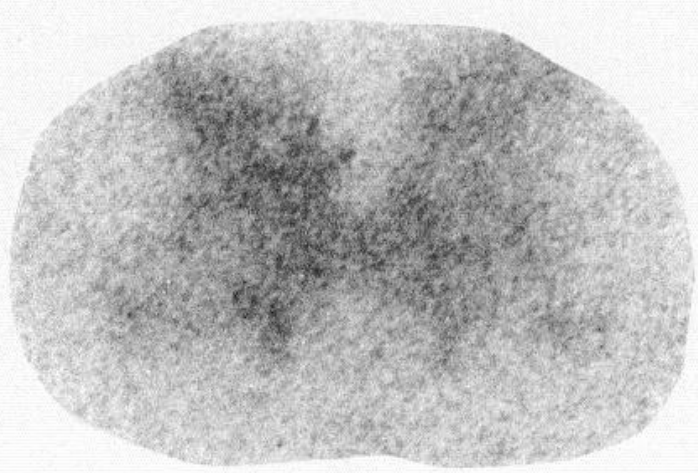


terns of hybridization were similar at the ccrvical and thoracic levels of the spinal cord (data not illustrated). GluR 1 mRNA was prominent throughout the layers of the gray matter of spinal cord, with no apparent gradient of expression between dorsal and ventral horns; labeling was at near background levels in white matter areas (Fig. $1 A$ ). Localized areas of intense labeling could be attributed to variations in the density of neuron packing. High-power, bright-field microscopy of emulsion-dipped sections revealed that hybridization grains overlay individual neuronal cell somata in all laminae of the spinal cord (see, e.g., Fig. 2A), whereas most of the darker and smaller nuclei (presumably glial) were not labeled (data not illustrated). In the ventral horn, dense aggregation of silver grains was visible over the cell bodies of individual motoneurons (data not shown). Film autoradiography indicated that GluR2 distribution was not uniform throughout spinal cord gray matter; GluR2 mRNA was abundant in the most dorsal laminae of the dorsal horn, in laminae 4,5 , and 10 , in the dorsal nucleus of Clarke, and in the motor cell columns of lamina 9 (Fig. 1C). The rest of the gray matter was labeled at lower intensity; white matter labeling was at near background (Fig. $1 C$ ). Low-power, dark-field microscopy of emulsion-dipped sections revealed striking labeling of laminae 1-3 of the dorsal horn; at higher magnification, brightfield microscopy revealed dense clusters of grains overlying neurons of laminae 1-3 and individual motor neurons (data not shown). GluR 3 and NR 1 hybridization signals in gray matter were at lower levels as compared to GluR1 and GluR2. In film autoradiograms, GluR3 labeling was appreciable in the motor neuron columns of lamina 9 and was very low in laminae 1-3 (where GluR 1 and GluR2 mRNAs were expressed at high levels) (Fig. $1 E$ ). NR 1 labeling appeared to be homogeneous among laminae of the dorsal and ventral horns (Fig. $1 G$ ).

Injection of LPS into the right ankle joint of rats produced joint swelling (Table 1) and caused a modification of AMPA/ kainate receptor subunit gene expression in the lumbar segments of the spinal cord (Figs. 1, 2). The size difference between the right and left ankle joint in LPS-injected rats increased at $6 \mathrm{hr}$ and was maximal $24 \mathrm{hr}$ postinjection; after $72 \mathrm{hr}$ it was not different from that measured in saline-injected rats (Table 1). Twenty-four hours after the injection, expression of GluR 1 was markedly and bilaterally reduced in the dorsal and ventral horns of lumbar spinal cord as compared to that in corresponding control sections; labeling in the laminae surrounding the central canal was reduced to a lesser degree (Fig. $1 A, B$ ). In contrast, no change was apparent in expression levels of GluR2, GluR3, or NR1 mRNAs in any region of the cord at this level (Fig. $1 C-$ $H$ ). The marked and selective decrease in GluR 1 expression in outer laminae of the dorsal horn $24 \mathrm{hr}$ after LPS injection was confirmed by microscopic observation of emulsion-dipped sections (Fig. 2). In arthritic rats, labeling of individual neurons of laminae $1-3$ was greatly reduced as compared to controls (Fig. $2 A, B)$. These findings indicate that the decrease in dorsal horn

\begin{abstract}
Table 1. Size difference (in $\mathrm{mm}$ ) between right and left hindpaw following injection of saline (10 $\mu \mathrm{l})$ or LPS $(10 \mu \mathrm{g}$ in $10 \mu \mathrm{l}$ of saline) into the right ankle joint of rats
\end{abstract}

\begin{tabular}{lll}
$\begin{array}{ll}\text { Time } \\
\text { postin- } \\
\text { jection }\end{array}$ & Joint swelling $(\mathrm{mm})$ & \\
\cline { 2 - 3 } & Saline $(n)$ & LPS $(n)$ \\
\hline $6 \mathrm{hr}$ & $0.15 \pm 0.09(4)$ & $1.10 \pm 0.12^{*}(4)$ \\
$24 \mathrm{hr}$ & $0.05 \pm 0.05(4)$ & $1.15 \pm 0.09^{* *}(4)$ \\
$72 \mathrm{hr}$ & $0.12 \pm 0.05(4)$ & $0.32 \pm 0.09$
\end{tabular}

Values are given as mean size difference \pm SEM. Swelling was maximal at $24 \mathrm{hr}$ postinjection and returned to control values after $72 \mathrm{hr}$.

$* p<0.05$ vs saline-treated rats after $6 \mathrm{hr}$, Mann-Whitney $U$ test.

${ }^{* *} p<0.01$ vs saline-treated rats after $24 \mathrm{hr}$, Mann-Whitney $U$ test.

GluR 1 determined by densitometric analysis of film autoradiograms represents a reduction of $\mathrm{mRNA}$ per neuron in laminae $1-3$.

Quantitative analysis of film autoradiograms revealed that 24 hr after LPS injection GluR I was selectively and bilaterally reduced in dorsal and ventral horns of lumbar spinal cord as compared to controls (Table 2). Since right and left optical density readings were similar for all probes in every region or time postinjection examined (see Table 2), they were averaged and calculated as a single value. GluR 1 was reduced by $25 \pm 7 \%(p$ $<0.05$ vs controls) in dorsal horn laminae of lumbar spinal cord, by $14 \pm 4 \%$ ( $p<0.05$ vs controls) in the ventral horn, and by $11 \pm 6 \%$ (not significant) in the central region (Table 2). Conversely, GluR2, GluR3, and NR1 mRNAs in LPS-injected rats were not significantly different from control values in any region of the spinal cord (Table 2). A time-course analysis of GluR 1 hybridization at the lumbar level of the spinal cord of LPS-treated rats showed that the decrease in labeling was modest at $6 \mathrm{hr}$ after the injection (not significant vs control), was maximal at 24 hr (by $25 \pm 7 \%$ in dorsal horn, $p<0.05$ vs control; by $14 \pm 4 \%$ in ventral horn, $p<0.05$ vs control), and was at near control levels at $72 \mathrm{hr}$ (Fig. 3). Examination of cross sections cut at different levels revealed that the largest reduction of GluR $1 \mathrm{mRNA}$ levels induced by LPS injection into the right ankle joint was maximal in lumbar segments of spinal cord, and that the reduction decreased with the distance from the lumbar region (Fig. 4).

\section{Discussion}

The presence of NMDA and non-NMDA glutamate receptors in the spinal cord and their involvement in primary afferent neurotransmission have been established by receptor autoradiography (Monaghan and Cotman, 1982, 1985; Greenamyre et al., 1984; Henley et al., 1993) and electrophysiological (Watkins and Evans, 1981; Salt and Hill, 1983; Watkins, 1984; Collingridge and Lester, 1989; Wilcox, 1991) studies. The present

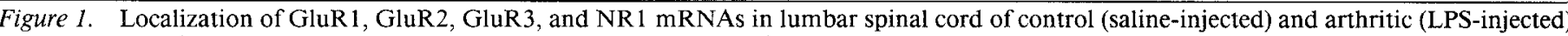

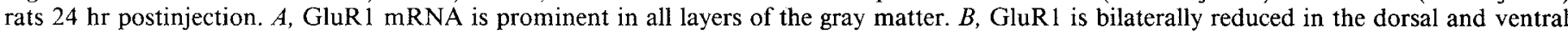

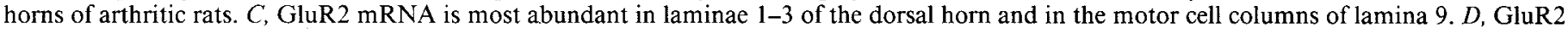

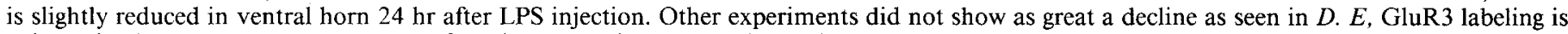

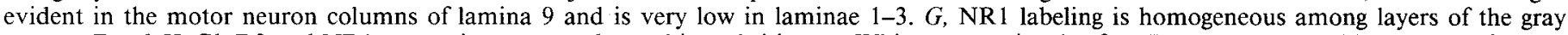

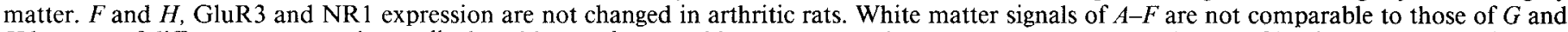

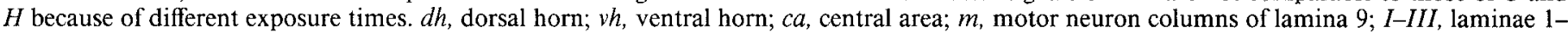
3. Scale bar, $1 \mathrm{~mm}$. 

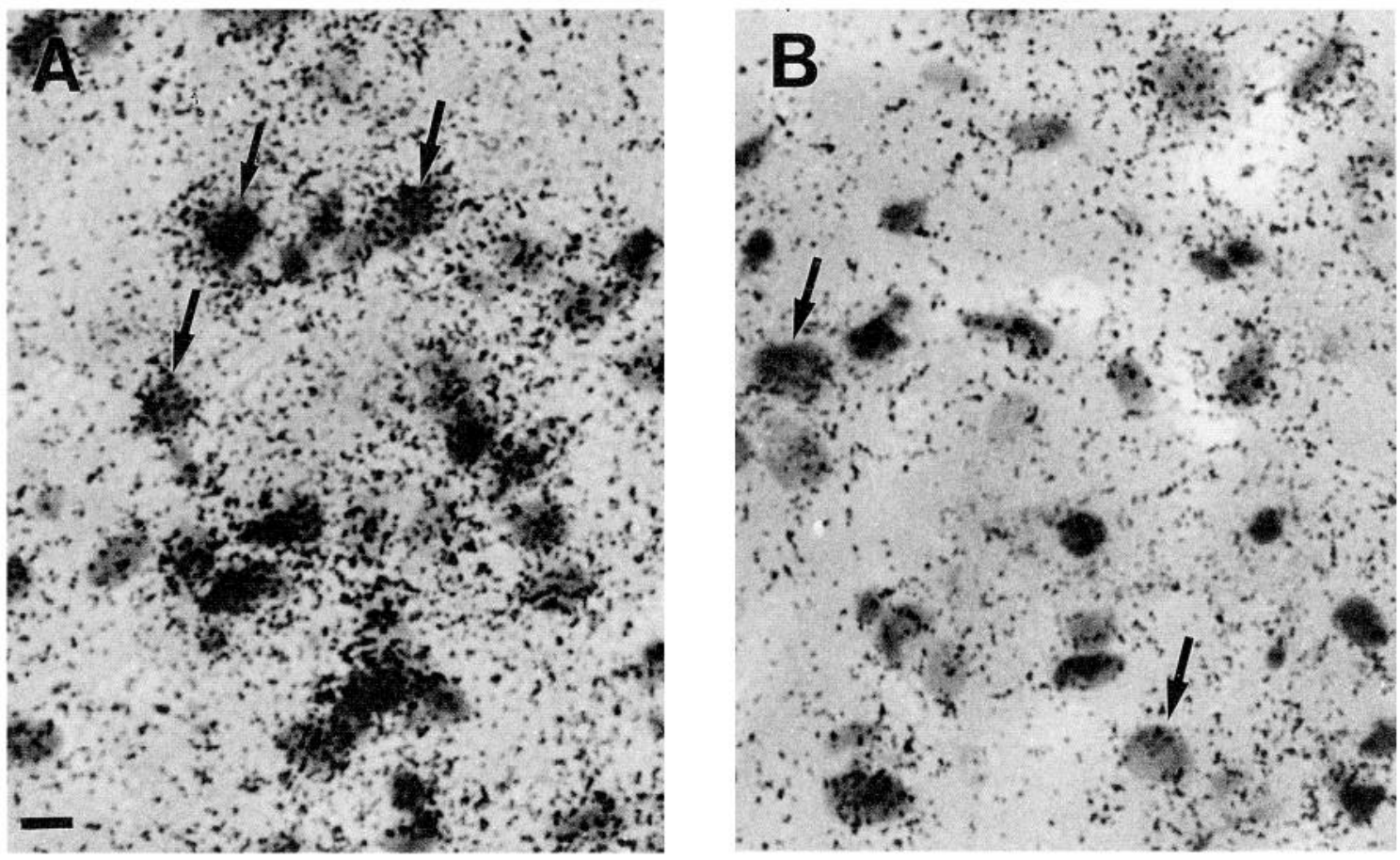

Figure 2. Emulsion-dipped slides showing in situ hybridization grains over individual neurons counterstained with hematoxylin and eosin. $A$, GluR1 mRNA expression in individual neurons (indicated by arrows) of substantia gelatinosa at the lumbar level. $B$, GluR1 hybridization grains are markedly reduced in the same area $24 \mathrm{hr}$ after LPS injection. Arrows depict individual neurons showing GluR 1 hybridization that approaches background. Scale bar, $6 \mu \mathrm{m}$.

study examined the expression of GluR1, GluR2, GluR3, and NR1 mRNAs in rat spinal cord using in situ hybridization histochemistry. Our results show that different neuronal populations in the spinal cord have different patterns of AMPA/kainate receptor subunit expression. For example, neurons in laminae 1-3 are enriched in GluR2 mRNA, whereas labeling of GluR1, GluR2, and GluR3 is uniformly high in motor neurons. Since the current-voltage relationship and cation permeability of ex-

Table 2. Hybridization densities in lumbar spinal cord sections from control (saline-injected) and arthritic (LPS-injected) rats $24 \mathrm{hr}$ postinjection

\begin{tabular}{|c|c|c|c|c|c|}
\hline & \multicolumn{5}{|c|}{ Hybridization densities (o.d./unit area $\times 100 \pm$ SEM) } \\
\hline & \multicolumn{2}{|c|}{ Control $(n=4)$} & \multicolumn{3}{|c|}{ Arthritic $(n=4)$} \\
\hline & Right & Left & Right & Left & $\%$ of control \\
\hline \multicolumn{6}{|c|}{ Dorsal horn } \\
\hline GluR1 & $38 \pm 2.5$ & $38 \pm 2.4$ & $28 \pm 2.1^{*}$ & $28 \pm 3.1^{*}$ & $-25 \pm 7 \%$ \\
\hline GluR2 & $46 \pm 2.6$ & $48 \pm 2.8$ & $42 \pm 2.1$ & $44 \pm 2.5$ & $-7 \pm 5 \%$ \\
\hline GluR3 & $20 \pm 0.8$ & $20 \pm 0.7$ & $19 \pm 0.5$ & $19 \pm 2.1$ & $-6 \pm 5 \%$ \\
\hline NR1 & $29 \pm 1.8$ & $26 \pm 0.5$ & $29 \pm 0.7$ & $29 \pm 0.8$ & $+7 \pm 10 \%$ \\
\hline \multicolumn{6}{|c|}{ Ventral horn } \\
\hline GluR1 & $33 \pm 2.1$ & $34 \pm 2.5$ & $27 \pm 2.4^{*}$ & $29 \pm 1.6^{*}$ & $-14 \pm 4 \%$ \\
\hline GluR2 & $24 \pm 2.2$ & $24 \pm 1.9$ & $24 \pm 3.0$ & $25 \pm 1.8$ & $+3 \pm 7 \%$ \\
\hline GluR3 & $17 \pm 1.5$ & $19 \pm 1.8$ & $16 \pm 1.4$ & $16 \pm 0.5$ & $-11 \pm 6 \%$ \\
\hline NR1 & $27 \pm 0.7$ & $26 \pm 0.4$ & $26 \pm 1.1$ & $28 \pm 0.5$ & $+2 \pm 2 \%$ \\
\hline \multicolumn{6}{|c|}{ Central region } \\
\hline GluR1 & $35 \pm 2.0$ & $36 \pm 2.2$ & $31 \pm 1.6$ & $32 \pm 2.3$ & $-11 \pm 6 \%$ \\
\hline GluR2 & $26 \pm 0.9$ & $26 \pm 2.1$ & $26 \pm 0.7$ & $28 \pm 1.8$ & $+4 \pm 5 \%$ \\
\hline GluR3 & $18 \pm 1.0$ & $18 \pm 1.2$ & $17 \pm 0.9$ & $19 \pm 1.9$ & $-2 \pm 5 \%$ \\
\hline NR1 & $29 \pm 0.7$ & $27 \pm 0.4$ & $29 \pm 0.4$ & $29 \pm 0.7$ & $+2 \pm 4 \%$ \\
\hline
\end{tabular}

Values are expressed as mean optical density readings per unit area $\times 100 \pm$ SEM. GluR1 hybridization levels are decreased in all regions of arthritic rats: reductions are significantly different from controls in dorsal and ventral horns but not in the central region. Reduction of GluR2 in dorsal horn and of GluR 3 in dorsal and ventral horns do not reach statistical significance. Dorsal horn values represent lamina 1-5 readings for GluR1 and GluR3 and lamina 1-3 readings for GluR2. In the "\% of control" column, right and left optical densities were averaged and calculated as a single value. ${ }^{*} p<0.05$ vs control, same side, Mann-Whitney $U$ test. 


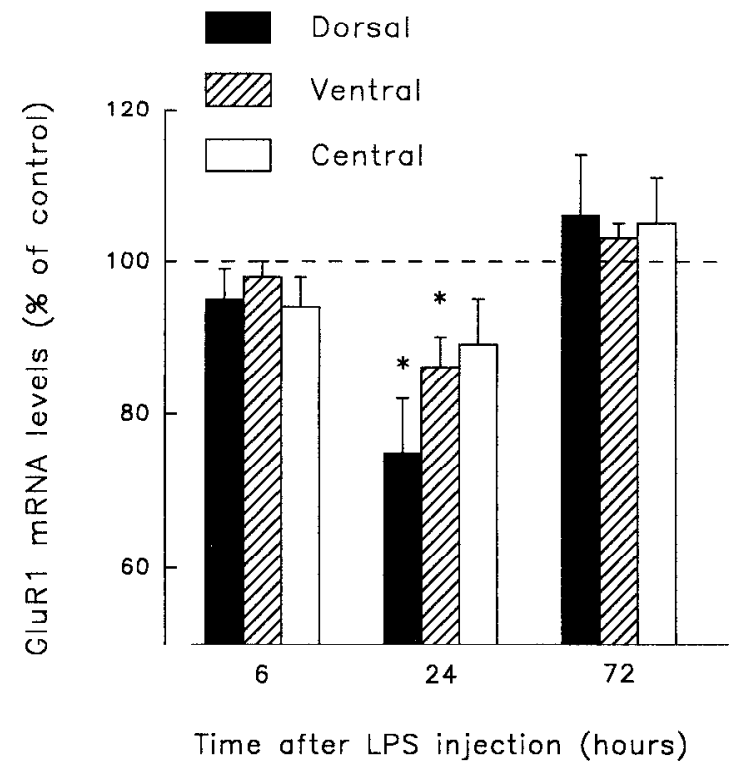

Figure 3. Expression of GluR $1 \mathrm{mRNA}$ as a function of time postinjection in dorsal, ventral, and central gray matter regions of lumbar spinal cord. Values are reported as percentage of control (saline-injected) optical densities \pm SEM. Right and left optical densities were averaged and calculated as a single value for each spinal cord region. GluR1 reduction is modest at $6 \mathrm{hr}$, maximal at $24 \mathrm{hr}$, and at control levels at $72 \mathrm{hr}\left(n=4\right.$ for each group). ${ }^{*}, p<0.05$ vs control, Mann-Whitney $U$ test.

pressed AMPA/kainate channels depend on their subunit composition (Gasic and Hollmann, 1992; Sommer and Seeburg, 1992), differences in mRNA content of neurons might correspond to differences in subunit composition and thus functional properties of spinal cord AMPA/kainate receptors. NR1 was expressed at lower levels as compared to GluR1 and GluR2, the distribution being homogeneous among layers. The latter finding is not surprising, considering that NR1 is expressed homogeneously in almost all areas in the brain (Moriyoshi et al., 1991). Members of the NR2 family, which confer functional diversity to heteromeric channels and are heterogeneously expressed in brain (Meguro et al., 1992; Kutsuwada et al., 1992; Monyer et al., 1992), are more likely to be expressed differentially in the spinal cord.

The present study indicates a distribution of glutamate receptor mRNAs in rat spinal cord that differs to some extent from the patterns determined by autoradiography. AMPA, kainate, and NMDA receptor binding sites are all densely concentrated in lamina 2 of the dorsal horn and of much lower density in the other laminae (Monaghan and Cotman, 1982, 1985; Greenamyre et al., 1984; Henley et al., 1993). Our results show that the expression of GluR2 only was highest in laminae 1-3; GluR1, GluR3, and NR1 exhibited more uniform labeling throughout the gray matter. Since mammalian cells transfected with GluR1, GluR2, or GluR3 cDNAs display high-affinity AMPA-selective binding pharmacology (Keinänen et al., 1990), GluR proteins should correspond to high-affinity ${ }^{3} \mathrm{H}$-AMPA sites detected by receptor studies. Thus, the distribution of ${ }^{3} \mathrm{H}$ AMPA binding may reflect the combined expression of GluR 1 , GluR2, and GluR3, which is maximal in laminae 1-3. Alternatively, differences may be explained by nonlinearity between mRNA content and protein expression, or by translocation of receptor protein to different sites.

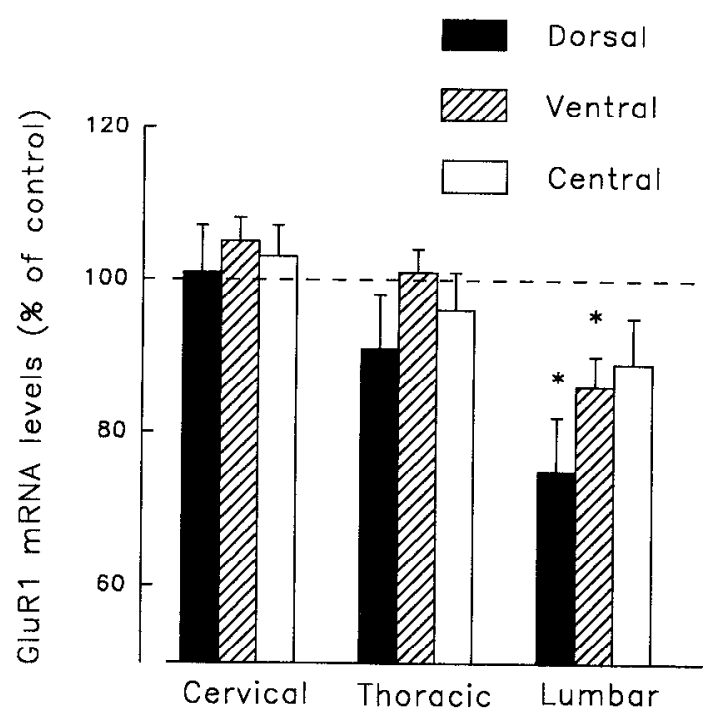

Figure 4. Expression of GluRI in cervical, thoracic, and lumbar segments of spinal cord $24 \mathrm{hr}$ after LPS injection into the right ankle joint of rats. Values are reported as percentage of control (saline-injected) optical densities \pm SEM. Right and left optical densities were averaged and calculated as a single value for each spinal cord region. GluR 1 is maximally decreased in lumbar segments and the reduction decreases as the distance from the lumbar spinal cord increases $(n=4$ for both saline- and LPS-injected groups). ${ }^{*}, p<0.05$ vs control, Mann-Whitney $U$ test.

LPS injection into the right ankle joint of rats caused swelling of the injected joint that was maximal $24 \mathrm{hr}$ postinjection and regressed thereafter. These results are consistent with previous observations of acute arthritis induced by intra-articular injection of LPS (Goldenberg et al., 1984; Esser et al., 1986; Stimpson et al., 1987). The inflammation was temporally associated with a bilateral and selective reduction of GluR 1 expression in the dorsal and ventral horns of lumbar spinal cord. Thus, GluR1, GluR2, GluR3, and NR1 mRNAs appear to be differentially regulated in response to prolonged noxious stimuli. This regulation may occur at the level of transcription or, alternatively, could be the result of a more rapid degradation of GluR 1 mRNA as compared to the other transcripts. Since homomeric GluR1 channels or recombinant heteromeric receptors containing GluR 1 exhibit the highest affinity for glutamate (Gasic and Hollmann, 1992; Stein et al., 1992), the selective reduction of GluR1 expression would be predicted to decrease postsynaptic neuronal responsiveness to increased release of glutamate from afferent terminals (Skilling et al., 1988; Sorkin et al., 1992). Thus, physiologically, GluR 1 gene expression plastic changes in spinal cord might represent a defensive mechanism in response to increased neuronal activity, rather than a mechanism for increased excitability of neurons and hyperalgesia (Dougherty et al., 1992).

Interestingly, unilateral ankle joint inflammation in these experiments led to bilateral, equal reduction of GluR 1 expression in lumbar spinal cord. This plasticity may be compared to the bilateral and equal increase in the number of NADPH-diaphorase-stained neurons observed in laminae 1-3 following unilateral hindpaw inflammation (Solodkin et al., 1992) and bilateral changes in opioid receptor binding subsequent to monoarthritis (Besse et al., 1992). In contrast, other studies have demonstrated significant, predominantly ipsilateral, changes in gene and protein expression (Iadarola et al., 1988; Ruda et al., 1988; Dubner and Ruda, 1992; Sluka et al., 1992) and dorsal 
horn neuron excitability (Woolf et al., 1988) in the spinal cord associated with peripheral inflammation and hyperalgesia. Several studies have demonstrated hyperalgesia in contralateral hindlimbs and forelimbs following unilateral hindpaw inflammation (Guilbaud et al., 1986, 1989; Kayser and Guilbaud, 1987). Bilateral changes in gene expression following unilateral inflammation could potentially be related to such pathophysiological phenomena.

In conclusion, GluR1, GluR2, GluR3, and NR1 genes displayed different patterns of expression in the rat spinal cord and a differential regulation in response to prolonged inflammation. These findings suggest that the subunits they encode have unique functions in the normal spinal cord and distinct roles in nociceptive neurotransmission.

\section{References}

Aanonsen LM, Wilcox GL (1989) Muscimol, $\gamma$-aminobutyric acid receptors and excitatory amino acids in the mouse spinal cord. $J$ Pharmacol Exp Ther 248:1034-1038.

Anantharam V, Panchal RG, Wilson A, Kolchine VV, Treistman SN, Bayley $H$ (1992) Combinatorial RNA splicing alters the surface charge on the NMDA receptor. FEBS Lett 305:27-30.

Ault B, Hildebrand L (1991) Glutamate receptor antagonist depression of a capsaicin-evoked nociceptive reflex. Soc Neurosci Abstr 17:1011.

Battaglia G, Rustioni A (1988) Coexistence of glutamate and substance $P$ in dorsal root ganglion neurons of the rat and monkey. J Comp Neurol 277:302-312.

Besse D, Weil-Fugazza J, Lombard M-C, Butler SH, Besson J-M (1992) Monoarthritis induces complex changes in $\mu-, \delta$ - and $\kappa$-opioid binding sites in the superficial dorsal horn of the rat spinal cord. Eur J Pharmacol 223:123-131.

Burnashev N, Monyer H, Sccburg PH, Sakmann B (1992) Divalent ion permeability of AMPA receptor channels is dominated by the edited form of a single subunit. Neuron 8:189-198.

Cahusac P, Evans R, Hill R, Rodriquez R, Smith D (1984) The behavioural effects of an $N$-methylaspartate receptor antagonist following application to the lumbar spinal cord of conscious rats. Neuropharmacology 23:719-724.

Cameron AA, Cliffer KD, Dougherty PM, Willis WD, Carlton SM (1991) Changes in lectin, GAP-43 and neuropeptide staining in the rat superficial dorsal horn following experimental peripheral neuropathy. Neurosci Lett 131:249-252.

Collingridge GL, Lester RAJ (1989) Excitatory amino acid receptors in the vertebrate central nervous system. Pharmacol Rev 40:143-210.

Davies SN, Lodge D (1987) Evidence for involvement of $\mathrm{N}$-methylaspartate receptors in "wind-up" of class 2 neurones in the dorsal horn of the rat. Brain Res 424:402-406.

De Biasi S, Rustioni A (1988) Glutamate and substance P coexist in primary afferent terminals in the superficial laminae of spinal cord. Proc Natl Acad Sci USA 85:7820-7824.

Dickenson A, Aydar E (1991) Antagonism at the glycine site on the NMDA receptor reduces spinal nociception in the rat. Neurosci Lett 121:263-266.

Dickenson AH, Sullivan AF (1987) Evidence for a role of the NMDA receptor in frequency dependent potentiation of deep rat dorsal horn nociceptive neurons following $C$ fibre stimulation. Neuropharmacology 26:1235-1238

Dickenson AH, Sullivan AF (1990) Differential effects of excitatory amino acid antagonists on dorsal horn nociceptive neurones in the rat. Brain Res 506:31-39.

Dougherty PM, Sluka KA, Sorkin LS, Westlund KN, Willis WD (1992) Neural changes in acute arthritis in monkeys. I. Parallel enhancement of responses of spinothalamic tract neurons to mechanical stimulation and excitatory amino acids. Brain Res Rev 17:1-13.

Dubner R, Ruda MA (1992) Activity-dependent neuronal plasticity following tissue injury and inflammation. Trends Neurosci 15:96103.

Durand GM, Gregor P, Zheng X, Bennett MVL, Uhl GR, Zukin RS (1992) Cloning of an apparent splice variant of the rat $N$-methyl-Daspartate receptor NMDAR1 with altered sensitivity to polyamines and activators of protein kinase C. Proc Natl Acad Sci USA 89:93599363.

Esser RE, Anderle SK, Chetty C, Stimpson SA, Cromartie WJ, Schwab $\mathrm{JH}$ (1986) Comparison of inflammatory reactions induced by intraarticular injection of bacterial cell wall polymers. Am J Pathol 122: 323-334.

Ganong AH, Lanthorn TH, Cotman CW (1983) Kynurenic acid inhibits synaptic and acidic amino acid-induced responses in the rat hippocampus and spinal cord. Brain Res 273:170-174.

Garry MG, Hargreaves KM (1992) Enhanced release of immunoreactive CGRP and substance $P$ from spinal dorsal horn slices occurs during carrageenan inflammation. Brain Res 582:139-142.

Gasic GP, Hollmann M (1992) Molecular neurobiology of glutamate receptors. Annu Rev Physiol 54:507-536.

Goldenberg DL, Reed JI, Rice PA (1984) Arthritis in rabbits induced by killed Neisseria gonorrhoeae and gonococcal lipopolysaccharide. J Rheumatol 11:3-8.

Greenamyre JT, Young AB, Penney J (1984) Quantitative autoradiographic distribution of $\mathbf{L}-\left[{ }^{3} \mathrm{H}\right]$ glutamate-binding sites in rat central nervous system. J Neurosci 4:2133-2144.

Guilbaud G, Kayser V, Benoist JM, Gautron M (1986) Modifications in the responsiveness of rat ventrobasal thalamic neurons at different stages of carrageenin-produced inflammation. Brain Res 385:86-98.

Guilbaud G, Benoist JM, Eschalier A, Kayser V, Gautron M, Attal N (1989) Evidence for central phenomena participating in the changes of responses of ventrobasal thalamic neurons in arthritic rats. Brain Res 484:383-388.

Haley JE, Sullivan AF, Dickenson AH (1990) Evidence for spinal $N$-methyl-D-aspartate receptor involvement in prolonged chemical nociception in the rat. Brain Res 518:218-226.

Henley JM, Jenkins R, Hunt SP (1993) Localisation of glutamate receptor binding sites and $m$ RNAs to the dorsal horn of the rat spinal cord. Neuropharmacology 32:37-41

Hollmann M, Hartley M, Heinemann S (1991) $\mathrm{Ca}^{2+}$ permeability of KA-AMPA-gated glutamate receptor channels depends on subunit composition. Science 252:851-853.

Hollmann M, Boulter J, Maron C, Bcaslcy L, Sulliman J, Pecht G, Heinemann S (1993) Zinc potentiates agonist-induced currents at certain splice variants of the NMDA receptor. Neuron 10:943-945.

Iadarola MJ, Brady LS, Draisci G, Dubner R (1988) Enhancement of dynorphin gene expression in spinal cord following experimental inflammation: stimulus specificity, behavioral parameters and opioid receptor binding. Pain 35:313-326

Jahr CE, Jessel TM (1985) Synaptic transmission between dorsal root ganglion and dorsal horn neurons in culture: antagonism of monosynaptic excitatory synaptic potentials and glutamate excitation by kynurenate. J Neurosci 5:2281-2289.

Jansen K, Faull R, Dragunow M, Waldvogel H (1990) Autoradiographic localization of NMDA, quisqualate and kainic acid receptors in human spinal cord. Neurosci Lett 108:53-57.

Jonas P, Sakmann B (1992) Glutamate receptor channels in isolated patches from $\mathrm{CA} 1$ and $\mathrm{CA} 3$ pyramidal cells of rat hippocampal slices. J Physiol (Lond) 455:143-171.

Kayser V, Guilbaud G (1987) Local and remote modifications of nociceptive sensitivity during carrageenin-induced inflammation in the rat. Pain 28:99-107.

Keinänen K, Wisden W, Sommer B, Werner P, Herb A, Verdoorn TA, Sakmann B, Seeburg PH (1990) A family of AMPA-selective glutamate receptors. Science 249:556-560.

Kutsuwada T, Kashiwabuchi N, Mori H, Sakimura K, Kushiya E, Araki K, Meguro H, Masaki H, Kumanishi T, Arakawa M, Mishina M (1992) Molecular diversity of the NMDA raceptor channel. Nature $358: 36-41$

Long SK, Smith DAS, Siarey RJ, Evans RH (1990) Effect of 6-cyano2,3-dihydroxy-7-nitro-quinoxaline (CNQX) on dorsal root-, NMDA-, kaniate-, and quisqualate-mediated depolarization of rat motoneurones in vitro. Br J Pharmacol 100:850-854.

Malmberg AB, Yaksh TL (1992) Hyperalgesia mediated by spinal glutamate or substance $P$ receptor blocked by spinal cyclooxygenase inhibition. Science 257:1276-1279.

Meguro H, Mori H, Araki K, Kushiya E, Kutsuwada T, Yamazaki M, Kumanishi T, Arakawa M, Sakimura K, Mishina M (1992) Functional characterization of a heteromeric NMDA receptor channel expressed from cloned cDNA. Nature 357:70-74.

Miller KE, Clements JR, Larson AA, Beitz AJ (1988) Organization 
of glutamate-like immunoreactivity in the rat superficial dorsal horn: light and electron microscopic observation. Synapse 2:28-36.

Monaghan DT, Cotman CW (1982) The distribution of $\left[{ }^{3} \mathrm{H}\right]$ kainic acid binding sites as determined by autoradiography. Brain Res 191: 387-403.

Monaghan DT, Cotman CW (1985) Distribution of $N$-methyl-D-aspartate-sensitive. L- $\left[{ }^{3} \mathrm{H}\right]$ glutamate-binding sites in rat brain. J Neurosci 5:2909-2919.

Monyer H, Sprengel R, Schoepfer R, Herb A, Higuchi M, Iomeli $H$, Burnashev N, Sakmann B, Seeburg P (1992) Heteromeric NMDA receptors: molecular and functional distinction of subtypes. Science 256:1217-1221.

Moriyoshi K, Masu M, Ishii T, Shigemoto R, Mizuno N, Nakanishi S (1991) Molecular cloning and characterization of the rat NMDA receptor. Nature 354:31-37.

Morris R (1989) Responses of spinal dorsal horn neurones evoked by myelinated primary afferent stimulation are blocked by excitatory amino acid antagonists acting at kainate/quisqualate receptors. Neurosci Lett 105:79-85.

Murray CW, Cowan A, Larson AA (1991) Neurokinin and NMDA antagonists (but not a kainic acid antagonist) are antinociceptive in the mouse formalin model. Pain 44:179-185.

Näsström J, Karlsson U, Post C (1992) Antinociceptive actions of different classes of excitatory amino acid receptor antagonists in mice. Eur J Pharmacol 212:21-29.

Pellegrini-Giampietro DE, Bennett MVL, Zukin RS (1991) Differential expression of three glutamate receptor genes in developing rat brain: an in situ hybridization study. Proc Natl Acad Sci USA 88: 4157-4161.

Pellegrini-Giampietro DE, Zukin RS, Bennett MVL, Cho S, Pulsinelli WA (1992) Switch in glutamate receptor subunit gene expression in CAl subfield of hippocampus following global ischemia in rats. Proc Natl Acad Sci USA 89:10499-10503.

Ruda MA, Iadarola MJ, Cohen LV, Young WS III (1988) In situ hybridization histochemistry and immunocytochemistry reveal an increase in spinal dynorphin biosynthesis in a rat model of peripheral inflammation and hyperalgesia. Proc Natl Acad Sci USA 85:622-626.

Salt TE, Hill RG (1983) Neurotransmitter candidates of somatosensory primary afferent fibres. Neuroscience 10:1083-1103.

Skilling SR, Smullin DH, Beitz AJ, Larson AA (1988) Extracellular amino acid concentration in dorsal sinal cord of freely moving rats following veratridine and nociceptive stimulation. J Neurochem 51 : 127-132.

Sluka KA, Dougherty PM, Sorkin LS, Willis WD, Westlund KN (1992) Neural changes in acute arthritis in monkeys. III. Changes in substance $\mathrm{P}$, calcitonin gene-related peptide and glutamate in the dorsal horn of the spinal cord. Brain Res Rev 17:29-38.
Solodkin A, Traub RJ, Gebhart GF (1992) Unilateral hindpaw inflammation produces a bilateral increase in NADPH-diaphorase histochemical staining in the rat lumbar spinal cord. Neuroscience 51: 495-499.

Sommer B, Seeburg PH (1992) Glutamate receptor channels: novel properties and new clones. Trends Pharmacol Sci 13:291-296.

Sommer B, Keinänen K, Verdoorn TA, Wisden W, Burnashev N, Herb A, Köhler M, Takagi T, Sakmann B, Seeburg PH (1990) Flip and flop: a cell-specific functional switch in glutamate-operated channels of the CNS. Science 249:1580-1585.

Sorkin LS, Westlund KN, Sluka KA, Dougherty PM, Willis WD (1992) Neural changes in acute arthritis in monkeys. IV. Time-course of amino acid release into the lumbar dorsal horn. Brain Res Rev 17 39-50.

Stein E, Cox JA, Verdoorn TA (1992) Agonist and antagonist pharmacology of recombinant glutamate receptor subtypes. Pharmacologist $34: 133$.

Stimpson SA, Esser RE, Carter PB, Sartor RB, Cromartie WJ, Schwab $\mathrm{JH}$ (1987) Lipopolysaccharide induces recurrence of arthritis in rat joints previously injured by peptidoglycan-polysaccharide. J Exp Med 165:1688-1702.

Sugihara H, Moriyoshi K, Ishii T, Masu M, Nakanishi S (1992) Structures and properties of seven isoforms of the NMDA receptor generated by alternative splicing. Biochem Biophys Res Commun 185: $826-832$.

Verdoorn TA, Burnashev N, Monyer H, Seeburg PH, Sakmann B (1991) Structural determinants of ion flow through recombinant glutamate receptor channels. Science 252:1715-1718.

Watkins JC (1984) Excitatory amino acids and central synaptic transmission. Trends Pharmacol Sci 5:373-376.

Watkins JC, Evans RH (1981) Excitatory amino acid transmitters. Annu Rev Pharmacol Toxicol 21:165-204.

Wilcox GL (1991) Excitatory neurotransmitters and pain. In: Proceedings of the VIth world congress on pain (Bond MR, Charlton JE, Woolf CJ, eds), pp 97-117. Amsterdam: Elsevier.

Willis WD (1985) Nociceptive afferent input to the dorsal horn. In: The pain system (Gildenberg PL, ed), pp 78-144. Basel: Karger.

Woolf CJ, Thompson WN (1991) The induction and maintenance of central sensitization is dependent on $N$-methyl-D-aspartate receptor activation; implications for the treatment of post-injury pain hyper. sensitivity states. Pain 44:293-299.

Woolf CJ, Thompson SWN, King AE (1988) Prolonged primary afferent induccd alterations in dorsal horn ncuroncs, an intraccllular analysis in vivo and in vitro. J Physiol (Lond) 83:255-266.

Woolf CJ, Shortland P, Coggeshall RE (1992) Peripheral nerve injury triggers central sprouting of myelinated afferents. Nature 355:75-78. 